\title{
ANALYSING THE RELATIONSHIP \\ BETWEEN HOTELS' INTERNAL \\ MARKETING AND EMPLOYEE \\ ENGAGEMENT DIMENSIONS
}

\section{ISTRAŽIVANJE VEZE IZMEĐU INTERNOG MARKETINGA U HOTELU I RAZLIČITIH DIMENZIJA ANGAŽMANA ZAPOSLENIKA}

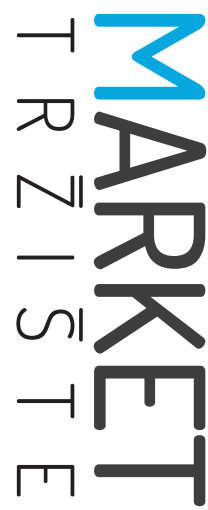

Vol. 32, Special Issue, 2020, pp. 49-65

UDK 658.8:640.412-057.16

DOl http://dx.doi.org/10.22598/mt/2020.32.spec-issue.49

Original scientific paper

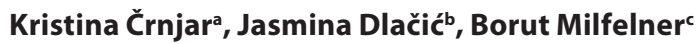 \\ a University of Rijeka, Faculty of Tourism and Hospitality Management, Primorska 42, 51410 Opatija, CROATIA, \\ e-mail:kcrnjar@fthm.hr \\ b University of Rijeka, Faculty of Economics and Business, Ivana Filipovića 4, 51000 Rijeka, CROATIA, \\ e-mail: jasmina.dlacic@efri.hr \\ ' University of Maribor, Faculty of Economics and Business, Razlagova 14, 2000 Maribor, SLOVENIA, \\ e-mail: borut.milfelner@um.si
}

\begin{abstract}
Purpose - In the hotel industry, as in all services, the goal is to have satisfied employees who are engaged in their job. From a marketing perspective, one of the possible ways companies can achieve that is by adopting internal marketing practices. Hence, the purpose of this paper is to research the relationship between internal marketing and different dimensions of employee engagement (emotional, cognitive and physical) in the hotel industry.
\end{abstract}

Design/Methodology/Approach - The data was collected through a paper-and-pencil questionnaire on a sample of 573 hotel employees in Croatia. Adapted scales from previous research were used for measuring research constructs using the back-translation technique. Conceptual model and hypotheses were tested with covariance based structural equation modelling.

Findings and implications - The results show that internal marketing had a positive and statistically significant impact on emotional and cognitive engagement. Cognitive engagement, in turn, had a positive impact on emotional and physical engagement, while emotional

\section{Sažetak}

Svrha - U hotelijerstvu, kao i u svim uslugama, cilj je imati zadovoljne zaposlenike koji su angažirani na svojim radnim mjestima. Kako bi se to postiglo, poduzeća implementiraju interni marketing. Stoga je svrha ovoga rada istražiti vezu između internog marketinga i različitih dimenzija angažmana zaposlenika (emocionalnog, kognitivnog i fizičkog) u hotelijerstvu.

Metodološki pristup - Podatci su sakupljeni anketnim upitnikom na uzorku od 573 zaposlenika u hotelima u Hrvatskoj. Mjerni instrument sastoji se od prilagođenih ljestvica iz prošlih istraživanja, a koristio se povratni prijevod s engleskoga na hrvatski jezik. Konceptualni model i hipoteze testirani su metodom strukturnih jednadžbi koji se zasnivaju na kovarijantnim strukturama.

Rezultati i implikacije - Rezultati upućuju na to da interni marketing ima pozitivan i statistički značajan utjecaj na emocionalni i kognitivni angažman zaposlenika u hotelijerstvu. Kognitivni angažman ima pozitivan utjecaj na emocionalni, ali i fizički angažman zaposlenika. Isto tako, emocionalni angažman ima pozitivan utjecaj na fizički angažman zaposlenika. 
engagement had a positive impact on physical engagement.

Limitations - The use of self-evaluations could potentially cause social desirability bias. The study is limited only to Croatian hotels, which might vary from hotel industries in other parts of the world.

Originality - This paper contributes to the development of internal marketing, as it identifies the relationship between internal marketing and different forms of employee engagement. Employee engagement is approached multidimensionally as consisting of emotional, cognitive and physical engagement. By distinguishing different engagement dimensions, the paper contributes to the theory of personal engagement with testing employee engagement concept in the hotel industry.

Keywords - internal marketing, employee engagement, hotel industry, hotels, Croatia
Ograničenja - U radu su korištene ljestvice koje koriste samoprocjenu, što može imati za posljedicu da ispitanici daju društveno poželjne odgovore. Istraživanje se fokusira i samo na Hrvatsku, čije hotelijerstvo može imati neke specifičnosti u odnosu na druge države.

Doprinos - Rad doprinosi razvoju praksi internoga marketinga i identificira veze između njega i različitih oblika angažmana zaposlenika. Angažman zaposlenika analizira se kao višedimenzionalan konstrukt koji se sastoji od emocionalnog, kognitivnog i fizičkog angažmana. Kroz razlikovanje njegovih različitih vrsta rad doprinosi teoriji osobnog angažmana kroz testiranje koncepta angažmana zaposlenika u hotelijerstvu.

Ključne riječi - interni marketing, angažman zaposlenika, hotelijerstvo, hoteli, Hrvatska 


\section{INTRODUCTION}

In the hotel industry, which is a service industry, the importance of competent and qualified employees is strongly emphasized (e.g. Balta, 2018). In addition, satisfied employees are important as they contribute to company performance by creating satisfied and loyal customers (Ahmed \& Rafiq, 2003). One way to achieve this is through the process of internal marketing, where the function of human resource management (HRM) and marketing meet. Berry (1981, p.25) pointed out that internal marketing is "viewing employees as internal customers". Hence, employees are perceived as organization's customers and are approached as such through internal communication. The company invests in them through training and developing their skills and abilities, and as a result they are motivated to do their job well and willing to stay in the company for a longer period of time (Akroush, Abu-ElSamen, Samawi \& Odetallah, 2013).

Employee engagement has been recognized as a prerequisite for business success (Slåtten \& Mehmetoglu, 2011). Engaged employees are focused on their work and prone to get the job done in the best possible way (Schaufeli \& Bakker 2004). They are cognitively interested in and aware of their job performance, they have and express positive emotions related to their job and are actively emerged in their performance (Rich, Lepine \& Crawford, 2010). Therefore, companies' goals are not set only to having satisfied employees or, in the context of internal marketing, having satisfied internal customers, but they also want engaged employees.

Employee engagement and internal marketing have been discussed and researched by many authors, such as Mitchell (2000), Czaplewski, Ferguson and Milliman (2001), Das (2003), Alves, do Paço and Roberto (2015) etc. They stress that organisation, and in particular managers, must create such working environment for their employees that will enhance employee engagement. Company's organisational value is perceived as high if employees are emotionally connected with their job and perceive their work positive- ly. To create an emotional relationship between employees and their job, companies should focus on developing and implementing internal marketing activities. Likewise, internal marketing should be perceived as a mean to motivate and retain employees in order to establish a strong engagement with their job.

Employee engagement can take many forms. According to Rich and others (2010), employees can be engaged through emotional cognitive and physical component. Therefore, the main purpose of this paper is to explore the relationship between internal marketing and different forms of employee engagement. More precisely, we want to address a research gap in literature on marketing and tourism, by exploring the influence of internal marketing on emotional, cognitive and physical dimension of engagement, as well as by exploring relationships between different forms of engagement in the framework of internal marketing impact in the hotel industry. Hence, the paper contributes in several ways. Firstly, it contributes to the field of internal marketing as it proposes and empirically tests relationships with multidimensional conceptualisation of employee engagement. Secondly, it further develops the theory of personal engagement by empirically testing multidimensional conceptualisation of employee engagement concept in the hotel industry and by exploring relationships between different dimensions.

The paper is structured into several key parts. After introduction, a theoretical background and hypotheses development are presented, followed by methodology, and finally the results. The paper ends with conclusions and managerial implications. In addition, limitations are stated and further research ideas identified.

\section{THEORETICAL BACKGROUND AND HYPOTHESES DEVELOPMENT}

\subsection{Internal marketing}

Internal marketing as a concept first emerged in service management. Employees were seen

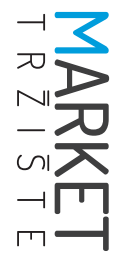




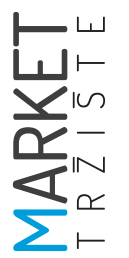

as internal customers, i.e. the customers of the organisation. It was stressed that in order to improve corporate success, companies should improve internal marketing relationships (Varey \& Lewis, 1999, Alves et al., 2015). Gounaris (2006) and Boukis, Gounaris and Lings (2017) similarly explain that internal marketing activities can be assessed by adopting the internal-market orientation (IMO) concept which reflects the company's capacity to implement the existing practices of human resources. Hence, IMO represents a strategic approach that guides internal marketing, which is perceived as a plan for IMO implementation (Sanchez-Hernandez \& Grayson, 2012). Moreover, in order to be successfully adapted and implemented in company practices, IMO requires that managers consider both marketing and human resource management (Sanchez-Hernandez \& Miranda, 2011). This indicates that there is a strong connection and overlapping of activities in internal marketing and human resource management. As implementing the IMO not only improves the value for the customer, but at the same time takes care of the company's employees (Gounaris, Chryssochoidis \& Boukis, 2020), it also strengthens human resources practices. However, Gounaris $(2006,435)$ asserts that "the fundamental conception of internal marketing remains behavioural, capturing the strategies and programs that the company implements internally in order to attain its external market objectives".

Definitions of internal marketing and of the set of dimensions it incorporates varies greatly. Ahmed and Rafiq (2003) define internal marketing as a set of integrating and coordinating activities within organizations which aim at creating links between external users and internal quality and ensuring continuous improvement, while focusing on organization's employees. Employees are important since they are responsible for implementing strategies and making continuous progress and improvements in products, services or processes in the organization. Depending on the focus of authors' re- search, internal marketing is seen as a synonym for human resource management and a marketing technique used in internal marketplace. It is also regarded as contributing to establishing satisfied external customers, as an element important for creating competitive advantages (Sinčić \& Pološki Vokić, 2007) and boostsing company's effectiveness (Teimouri, Chegini, Jenab, Khoury \& LaFevor, 2016).

In addition to a variety of definitions of internal marketing, there is also a lack of agreement among authors on the dimensions that are incorporated in internal marketing. In their research, Akroush and others (2013) pointed out that internal marketing consists of the following dimensions: staff motivation, staff recruitment, internal communication, staff training, staff retention and job security. They concluded that employee recruitment, employee training and internal communication have a significant positive effect on employee motivation. Staff motivation, in turn, will have a direct positive effect on job security and staff retention. Several other studies (e.g. Chang \& Chang, 2007, Tsai \& Tang, 2008, Braimah, 2016) suggest internal marketing has additional dimensions, such as identifying, attracting, developing, retaining and motivating employees, administrative support, internal communication, training and development, teamwork, incentive systems and empowerment.

In the hotel industry and hospitality in general, employee performance and attitudes are significant factors affecting the degree of service quality delivered by employees to clients (Ruizalba, Bermundez-Gonzalez, Rodriguez Molina \& Blanca, 2014). Implementing internal market orientation practices improves the perception of service quality among customers, by enhancing the value employees perceive to be receiving from their company (Gounaris, Vassilikopoulou \& Chatzipanagiotou, 2010). Therefore, internal marketing practices contribute to the success of the organisation by enhancing service quality. 


\subsection{Employee engagement}

In recent years, employee engagement has spurred considerable interest among businesses. A lack of workers with key competences on the labour market, difficulties in retaining key employees and motivating the existing ones emphasize greater need to incorporate employee engagement issues in strategic development plans. Studies are increasingly exploring the influence of practices of human resources (such as motivation, training and development, etc.) on employees' engagement and performance (Rich et al., 2010, App, Merk \& Buttgen, 2012, Truss, Shantz, Soane, Alfes \& Delbridge, 2013, Sattar, Ahmad \& Mahnaz Hassan, 2015, Brook, 2019).

Khan (1990) introduced the concept of employee engagement, and was followed by researchers such as Saks (2006), Vance (2006), and Hansen, Byrne and Kiersch (2014), who took this concept as the basis of their research. According to these authors, job engagement can be approached multidimensionally, focusing on individual's physical, cognitive and emotional enthusiasm in work performance. Kahn defined engagement as "the simultaneous employment and expression of a person's preferred self in task behaviours that promote relationship to work and to others, personal presence (physical, cognitive and emotional) and active, full performances" (Khan, 1990, p. 700). Kahn noted that employees are more engaged in the situation when they are more physically immersed in the task they have to preform, when they are cognitively attentive, focused and caring, as well as more emotionally attached to the task and the environment (other employees). Emotionally engaged employees are passionate about their work, they form meaningful connections with working colleagues, and are emphatic and concerned for feelings of other employees. Cognitively engaged employees devote more attention to their work and are more aware of their role in the company. Physically engaged employees view work as a source of energy and they put greater effort into their work. Higher engagement of employees in each dimension results in higher comprehensive personal engagement.
Employee engagement is important for employees' individual satisfaction and wellbeing. Engaged employees are more connected to their everyday tasks and dedicated to the overall success of the organization. Moreover, they stay in the company longer regardless of new opportunities that may arise elsewhere. They care more about their colleagues, and become more productive as well as more efficient. All this results in greater profitability, superior customer satisfaction, enhanced task performance, better morale and motivation, as well as increased organisational citizenship behaviour (Samra, Gilbert, Shain \& Bilsker, 2012, p. 4). If employees have low social interaction in their job, little autonomy in decision-making, and perceive that their job is not important, they start to feel disengaged and withdraw cognitively and emotionally. Companies with disengaged employees are more likely to have a higher employee turnover, workplace deviance and counterproductive and withdrawal behaviour (Luthans \& Peterson 2002).

Effective human resource practices are a significant tool for enhancing employees' perceived efficiency and engagement level (Shuck \& Wollard 2010, Truss et al., 2013, Aktar \& Pangil, 2017). In terms of HRM practices, if employees perceive that they have a high level of social interaction within the organization, they are more likely to be satisfied in their job and more engaged. This is likely to enhance synergy in the workplace and results in higher and sustained performance. When employees perceive the environment in the company to be supportive, they will cope with the work demand better (Sivapragasam \& Raya, 2018, p. 158). An organization with a consistent set of HRM practices and positive working climate is more likely to benefit from positive and engaged employees.

\subsection{Conceptual model and hypotheses}

When analysing internal marketing as an element of human resource management, we focus our attention to HRM processes (Sinčić \& Pološki Vokić, 2007). Successful development 


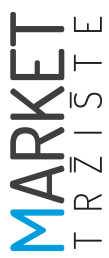

and implementation of HRM processes, such as staff recruitment, staff training, staff motivation or staff retention, will have direct and positive impact on employees' engagement, since employees are put in the centre of all these processes (Akroush et al., 2013). Moreover, if HRM processes focus on the selection of motivated and knowledgeable employees, constantly invest in their education, create an environment in which they will be appreciated and motivated to give their best and have good communication with their colleagues (Gjurašić \& Lončarić, 2018), employees will have a high level of personal satisfaction (Rich et al., 2010). This will result in employees who are vigilant and devoted to their work in order to achieve the company's mission (cognitive engagement). They will also be focused, attentive, loyal, empowered, creative, innovative (Ružić \& Benazić, 2018), emotionally connected to the working environment (emotional engagement) (Ruizalba et al., 2014) and more socially responsible (Sanchez-Hernandez \& Grayson, 2012). Hence, we propose the following:

H1: Hotel's internal marketing has a positive impact on employees' cognitive engagement.

H2: Hotel's internal marketing has a positive impact on employees' emotional engagement.

The researched employee engagement dimensions - cognitive, emotional and physical - are interconnected and affect one another (Khan, 1990). High cognitive engagement among employees often results in higher physical involvement and passion (Ho, Wong \& Lee 2011). While performing their job they encourage establishing emotional connections with their colleagues and loyalty towards the company. Employees that perceive their role in achieving the company's mission and goals as important (Samra et al., 2012) will be more willing to put additional effort into the work they are performing. The more employees identify with the working environment and the company, the more likely they are to be more physically involved in preforming the tasks and perceive the work as a source of energy, and not a burden. Employees will regard the success of the company and of the entire team as their personal success, which will bring individual satisfaction (Casey, 2017). A company with emotionally, physically and cognitively engaged employees is more likely to have a lower turnover, less behaviour unacceptable in the workplace, greater profitability, greater customer satisfaction and enhanced task performance (Luthans \& Peterson, 2002, Samra et al., 2012). Based on everything stated above, we propose the following:

H3: Employee cognitive engagement has a positive impact on employee emotional engagement.

H4: Employee cognitive engagement has a positive impact on employee physical engagement.

H5: Employee emotional engagement has a positive impact on employee physical engagement.

Conceptual model is presented in Figure 1.

\section{METHODOLOGY}

\subsection{Measurement instrument}

In analysing internal marketing, four variables (internal communication, training, loyalty and motivation) were used to operationalize four sub-constructs using 22 items. This scale was adopted from Akroush and others (2013), and the items were measured with a 7-point Likert scale. Four items were used for internal communication, seven for motivation, five for loyalty and four for training. Additional 15 items from Rich et al. (2010) were used to measure three dimensions of employee engagement, namely emotional (five items), cognitive (five items) and physical engagement (five items). This scale was also designed as a 7-point Likert scale. Adapted scales were used for measuring research constructs using the back-translation technique.

\subsection{Data analysis}

The data was analysed with the covariance-based structural equation modelling (CB- 
FIGURE 1: Conceptual model

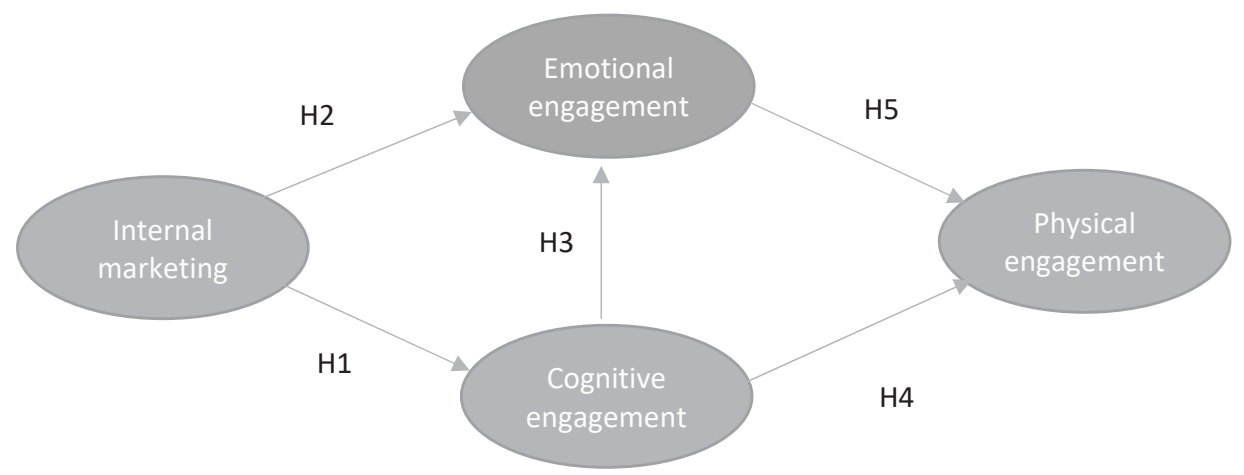

Source: Authors

SEM) using IBM SPSS 24.0 and IBM SPSS AMOS 24.0. CB-SEM is used in the analysis of a regression model, when predicting one or more dependent latent variable from a set of one or more independent latent variables. It is also useful in settings where dependent variables are also the predictors of other dependent variables. Besides the structural part linking the latent variables to each other, the measurement part links observed variables to latent variables (Kaplan, 2008). CB-SEM is an appropriate method for hypotheses testing when reflective measured constructs are specified, the structural model is not complex, the sample size is large enough, the goal is theory testing, theory confirmation, or the comparison of alternative theories, and the research requires a global goodness-of-fit criterion (Hair et al., 2011).

\subsection{Research sample}

The data was collected using a method of personal interviewing with a questionnaire on a sample of 573 hotel employees in Croatia. The collection process took place in the period between March and June 2018. Hotels were sampled based on their location. Research focus was on the hotels located in Croatia's Adriatic region (Ministry of Tourism, the Republic of Croatia, 2018) and only five employees per hotel were eligible to enter the research sample. Initially, 2675 hotel employees were asked to participate in the research. After screening the collected questionnaires, 31 of them were disregarded as they were incomplete. This results in the response rate of $21.4 \%$.

Sample characteristics are presented in Table 1. Most of the respondents included in the sample were female (56.9\%), in the age group between 21 and 30 (49.7\%), with secondary school education (45.9\%) and employed full time (38.2\%).

\subsection{Validity and reliability of the scales}

The reliability of constructs was assessed with Cronbach's alpha and the composite reliability indicator, which is the squared correlation between a construct and an unweighted composite of its indicators (Fornell \& Larcker, 1981). Convergent and discriminant validity were tested with the confirmatory factor analysis (CFA). The average variance extracted (AVE) was calculated for assessing convergent validity and Fornell-Larcker test (Fornell \& Larcker, 1981) and heterotrait-monotrait ratio of correlations (HTMT) was deployed (Hensler, Ringle \& Sarstedt, 2015) for the assessment of discriminant validity.

In order to achieve higher parsimony, internal marketing constructs have been included in the model as a second order construct with four indicators, namely motivation, loyalty, training and internal communication. Items for internal marketing second order constructs, its means, standard deviations and Cronbach's alphas are 
TABLE 1: Sample characteristics

\begin{tabular}{|c|c|c|c|}
\hline Gender & Frequency & Percent & Cumulative Percent \\
\hline male & 247 & 43.1 & 43.1 \\
\hline female & 326 & 56.9 & 100.0 \\
\hline Total & 573 & 100.0 & \\
\hline \multicolumn{4}{|l|}{ Age } \\
\hline $21-30$ & 285 & 49.7 & 49.7 \\
\hline $31-40$ & 164 & 28.6 & 78.4 \\
\hline $41-50$ & 69 & 12.0 & 90.4 \\
\hline $51-60$ & 53 & 9.2 & 99.7 \\
\hline 61 or more & 2 & 0.3 & 100.0 \\
\hline Total & 573 & 100.0 & \\
\hline \multicolumn{4}{|l|}{ Education } \\
\hline primary school & 2 & 0.3 & 0.3 \\
\hline secondary school & 263 & 45.9 & 46.2 \\
\hline undergraduate study & 92 & 16.1 & 62.3 \\
\hline graduate study & 78 & 13.6 & 75.9 \\
\hline post graduate study & 130 & 22.7 & 98.6 \\
\hline doctoral study & 8 & 1.4 & 100.0 \\
\hline Total & 573 & 100.0 & \\
\hline \multicolumn{4}{|l|}{ Employment status } \\
\hline employed during the season & 183 & 31.9 & 31.9 \\
\hline part time & 161 & 28.1 & 60.0 \\
\hline full time & 219 & 38.2 & 98.3 \\
\hline student work & 8 & 1.4 & 99.7 \\
\hline owner & 2 & 0.3 & 100.0 \\
\hline Total & 573 & 100.0 & \\
\hline
\end{tabular}

Source: Research results

presented in Appendix 1. Second order indicators were calculated with first assessing the reliability (all Cronbach's alpha were higher than 0.6) and then with averaging the items of each construct.

After the initial confirmatory factor analysis (CFA) and measurement model fit assessment $\left(X^{2}(80)=\right.$ 332.17; $\quad \mathrm{p}<0.001 ; \quad \mathrm{RMSEA}=0.072 ; \quad \mathrm{GFI}=0.928$; $\mathrm{NFI}=0.955 ; \mathrm{TLI}=0.958 ; \mathrm{IFI}=0.966 ; \mathrm{RMR}=0.087$ ), average variance extracted (AVE) and composite reliability (CR) measures were calculated. The results are presented in Table 2 . The values of indicator loadings were between 0.73 and 0.93 . All lambdas exceeded the suggested threshold of 0.6. Composite reliabilities were between 0.85 and 0.90 and were also inside the suggested intervals, meaning that scales were reliable. Average variance extracted (AVE) coefficients varied between 0.59 and 0.81 , all exceeding the suggested limit of 0.5 , despite the fact that the second order construct was calculated, that can sometimes lower AVE (Homburg \& Pflesser, 2000). The next was the Fornell-Larcker test (Fornell \& Larcker, 1981), which indicated that 
TABLE 2: Indicators loadings, composite reliabilities and average variances extracted of latent variables

\begin{tabular}{|c|c|c|c|c|}
\hline Items / second order constructs & Constructs & Lambdas & CR & AVE \\
\hline Motivation* & \multirow{4}{*}{ 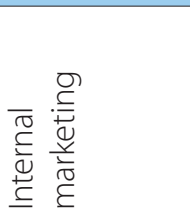 } & 0.760 & \multirow[t]{4}{*}{0.850} & \multirow[t]{4}{*}{0.588} \\
\hline Loyalty* & & 0.838 & & \\
\hline Training* & & 0.731 & & \\
\hline Internal communication* & & 0.733 & & \\
\hline I feel positive about my job. & \multirow{3}{*}{ 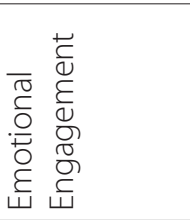 } & 0.887 & \multirow[t]{3}{*}{0.925} & \multirow[t]{3}{*}{0.803} \\
\hline I'm proud of my job. & & 0.899 & & \\
\hline I'm interested in my job. & & 0.903 & & \\
\hline At work, I focus a great deal of attention on my job. & \multirow{4}{*}{ 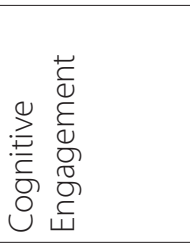 } & 0.855 & \multirow[t]{4}{*}{0.913} & \multirow[t]{4}{*}{0.724} \\
\hline At work, I concentrate on my job. & & 0.829 & & \\
\hline At work, I am absorbed by my job. & & 0.875 & & \\
\hline At work, I devote a lot of attention to my job. & & 0.845 & & \\
\hline I try my hardest to perform well on my job. & \multirow{4}{*}{ 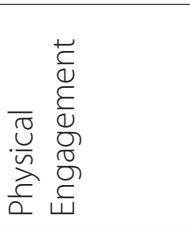 } & 0.885 & \multirow[t]{4}{*}{0.944} & \multirow[t]{4}{*}{0.809} \\
\hline I exert a lot of energy on my job. & & 0.888 & & \\
\hline I strive as hard as I can to complete my job. & & 0.927 & & \\
\hline I work with intensity on my job. & & 0.898 & & \\
\hline
\end{tabular}

Note: * Items for internal marketing second order constructs are presented in Appendix 1 Source: Research results

convergent validity was achieved. The obtained correlation between latent constructs and square roots of AVE are presented in Table 3. As can be seen, the square roots calculations of AVE are higher than correlations between the constructs for all cases, showing that discriminant validity is also in the suggested intervals. Additionally, more rigorous test presented in Table 4 also indicates no problems with discriminant validity, since HTMT ratios of correlations were all lower than the suggested 0.85 (Hensler et al., 2015).

\section{RESULTS}

The structural equation modelling was performed with the maximum likelihood (ML) es- timation. An overall fit assessment of the model yielded a significant chi-square value $\left(X^{2}(85)=\right.$ 338.44; $p<.001$ ) which indicates a non-perfect fit. However, according to Bollen (1989), other fit indices should be used, since $x^{2}$ may be an inappropriate standard when dealing with a complex model and large sample size. In this study, RMSEA, GFI, NFI, TLI, IFI and RMR fit indices were used to assess the overall model fit. The following indices were calculated for the structural model: RMSEA $=0.072 ; \mathrm{GFI}=0.928$; $N F I=0.954 ; \mathrm{TLI}=0.957 ; \mathrm{IFI}=0.966 ; \mathrm{RMR}=0.091$. All indices were in the accepted boundaries RM$\mathrm{SEA}<0.08 \mathrm{CFl}>0.90, \mathrm{NFI}>0.95, \mathrm{TL}|>0.90,| \mathrm{Fl}>0.90$, as proposed by representative authors in the field (Byrne, 1994, MacCallum, Browne \& Sugawara, 1996, Hu \& Bentler, 1999). The final struc- 
TABLE 3: Square Roots of the AVE and Correlations among the latent variables

\begin{tabular}{|l|c|c|c|c|}
\hline & $\begin{array}{c}\text { Internal } \\
\text { marketing }\end{array}$ & $\begin{array}{c}\text { Emotional } \\
\text { engagement }\end{array}$ & $\begin{array}{c}\text { Cognitive } \\
\text { engagement }\end{array}$ & $\begin{array}{c}\text { Physical } \\
\text { engagement }\end{array}$ \\
\hline $\begin{array}{l}\text { Internal } \\
\text { marketing }\end{array}$ & $0.767^{*}$ & & & \\
\hline $\begin{array}{l}\text { Emotional } \\
\text { engagement }\end{array}$ & 0.571 & $\mathbf{0 . 8 9 6 *}$ & $\mathbf{0 . 8 5 1 *}$ & \\
\hline $\begin{array}{l}\text { Cognitive } \\
\text { engagement }\end{array}$ & 0.530 & 0.837 & 0.745 & $\mathbf{0 . 8 9 9 *}$ \\
\hline $\begin{array}{l}\text { Physical } \\
\text { engagement }\end{array}$ & 0.501 & 0.711 & & \\
\hline
\end{tabular}

Note: * - square roots of AVE

Source: Research results

TABLE 4: HTMT analysis

\begin{tabular}{|l|c|c|c|}
\hline & $\begin{array}{c}\text { Internal } \\
\text { marketing }\end{array}$ & $\begin{array}{c}\text { Emotional } \\
\text { engagement }\end{array}$ & $\begin{array}{c}\text { Cognitive } \\
\text { engagement }\end{array}$ \\
\hline Emotional engagement & 0.583 & & \\
\hline Cognitive engagement & 0.544 & 0.837 & \\
\hline Physical engagement & 0.530 & 0.711 & 0.742 \\
\hline
\end{tabular}

Source: Research results

tural model and path coefficients are presented in Figure 2.

The analysis of the latent path coefficients shows that internal marketing had a positive and statistically significant impact on emotional $\left(\beta_{1}=0.18 ; p<0.001\right)$ and cognitive engagement $\left(\beta_{2}=0.53 ; p<0.001\right)$. According to that finding, we supported hypotheses $\mathrm{H} 1$ and $\mathrm{H} 2$. Cognitive engagement had a positive and significant impact on emotional $\left(\beta_{3}=0.74 ; p<0.001\right)$ and physical engagement $\left(\beta_{4}=0.50 ; p<0.001\right)$, meaning that hypotheses $\mathrm{H} 4$ and $\mathrm{H} 5$ were also supported. Finally, emotional engagement had a positive and statistically significant impact on physical engagement $\left(\beta_{5}=0.30 ; p<0.001\right)$, which gives support to $\mathrm{H} 3$.

Emotional and cognitive engagement mediated all impacts of internal marketing on physical engagement. The cognitive engagement mediated the impact of internal marketing on emotional engagement. The strength of the statistically significant $(p<0.001)$ indirect impact was 0.397 .

It is hard to evaluate from the proposed model which aspects of hotels' internal marketing (motivation, communication, training or internal communication) are more important for achieving higher employee engagements level, since internal marketing indicators are manifest variables and engagement variables are latent variables. Therefore, a post-hoc analysis was carried out, where factor scores for emotional, cognitive and physical engagement were calculated based on the underlying CFA. Afterwards we evaluated the correlations between single internal marketing indicators and three engagement factor scores. The results showed that internal communication is the most important factor in achieving all three types of employee engagement. 
FIGURE 2: Structural model and path coefficients

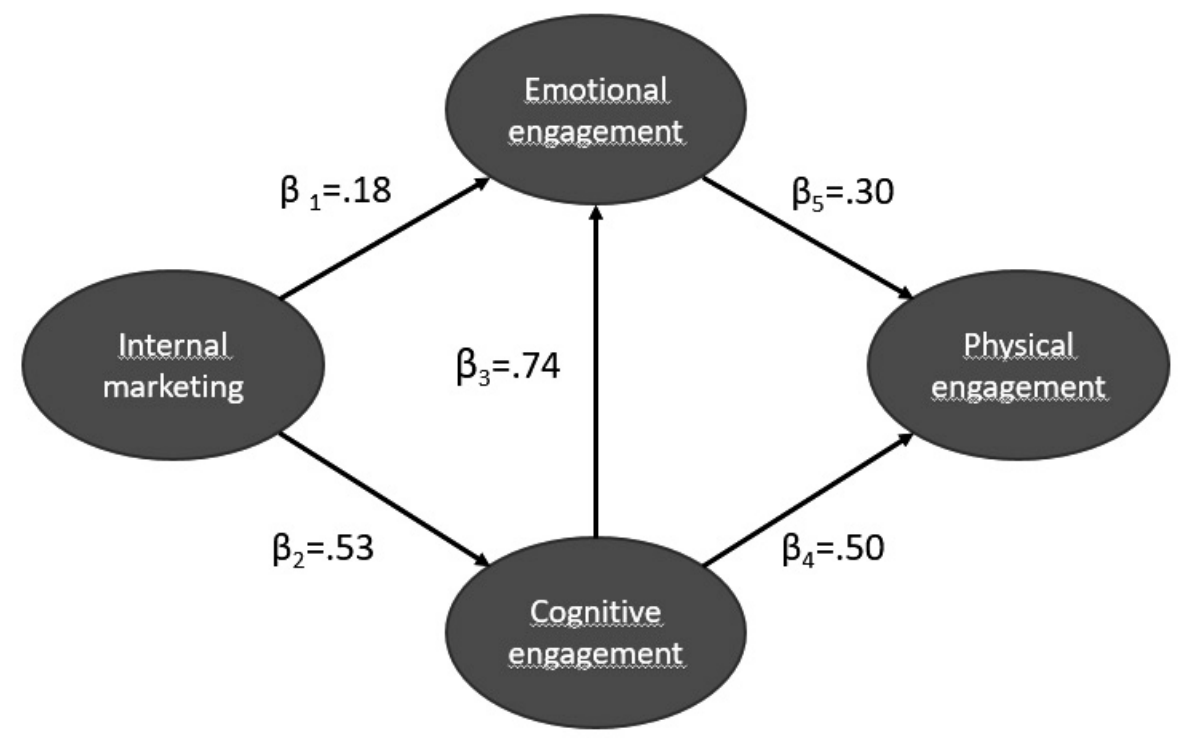

Source: Research results

\section{CONCLUSIONS}

The paper contributes to the development of the theory of internal marketing as it identifies the relationship between internal marketing and different forms of employee engagement. Employee engagement is approached multidimensionally as consisting of emotional, cognitive and physical engagement. By distinguishing different engagement dimensions, the paper contributes to the theory of personal engagement by testing employee engagement concept in the hotel industry.

This paper makes several contributions. Firstly, it is argued that different internal marketing activities, such as having motivated employees, establishing loyalty towards company, using internal communication effectively and investing in employee training, will enhance employee engagement. These practices enhance cognitive engagement more than emotional engagement. Hence, if a company invests in internal marketing practices, it will result in more focused and devoted employees as well as higher job performance. Similarly, Roknić and First Komen (2015) argue that although internal marketing practices are not well developed in Croatia, they contribute to establishing the desired corporate culture, so if managers want to establish a corporate culture in which employ-

TABLE 5: Correlations between internal marketing indicators and engagement factor scores

\begin{tabular}{|l|c|c|c|}
\hline & $\begin{array}{c}\text { Cognitive } \\
\text { engagement }\end{array}$ & $\begin{array}{c}\text { Emotional } \\
\text { engagement }\end{array}$ & $\begin{array}{c}\text { Physical } \\
\text { engagement }\end{array}$ \\
\hline Internal marketing - Motivation & 0.338 & 0.390 & 0.334 \\
\hline Internal marketing - Loyalty & 0.427 & 0.464 & 0.347 \\
\hline Internal marketing - Training & 0.358 & 0.368 & 0.376 \\
\hline Internal marketing - Internal communication & 0.597 & 0.616 & 0.591 \\
\hline
\end{tabular}

Note: All correlations were significant at $p<0.01$.

Source: Research results 


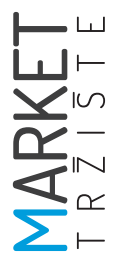

ees devote their attention to their job, they should implement internal marketing practices. Internal marketing practices boost customer satisfaction (Kadić-Maglajlić, Boso \& Micevski, 2018), which is an element especially important in business.

Secondly, by enhancing cognitive engagement, companies will positively influence emotional and physical engagement. Therefore, through different internal marketing activities and with employees committed to their work, companies can enhance employees' positive feelings about their job. Also, with these activities companies can boost employees' sense of pride for and interest in their work.

Thirdly, by affirming employees' commitment to their job, companies can also boost employees' job performance, focus and motivation to perform their work effectively. Similarly, Ružić and Benazić (2018) state that internal marketing practices boost sales innovativeness and new product selling. Hence, by applying internal marketing practices and increasing employee engagement, both cognitive and physical, companies can boost different aspects of employees' performance, such as sales.

Fourthly, according to research results, internal market activities can directly and indirectly impact employee engagement. The impact of internal marketing on emotional engagement is weaker than its impact on cognitive engagement. However, according to our results, internal marketing also has an important indirect impact on emotional engagement through cognitive engagement. Despite the fact that cognitive engagement (commitment, concentration and focus on work activities) is the most important factor for employees' physical engagement, our study shows that emotional engagement (feeling positive about the job, liking the job and having interest in job activities) is not insignificant when physical engagement of employees is taken into consideration. Finally, we tested the relationships of different internal marketing elements on employee engagement dimensions. Research results have shown that internal communication as internal marketing element has the strongest correlation with all employee engagement dimensions, the strongest correlation being with emotional engagement. Also, other internal marketing elements, such as motivation and loyalty, have the highest correlation with emotional engagement, except for training, which has the highest correlation with physical engagement.

Additionally, our research points to several managerial implications. Hotels can improve employee engagement by implementing internal marketing practices. Hence, hotels' marketing managers and human resource managers have to consider investing in internal marketing in order to have more engaged employees. Internal marketing positively influences employee focus, awareness and mindful job performance (cognitive engagement). Also, by improving cognitive engagement it is possible to have employees that are emotionally connected to their work as well as those more physically involved in performing different tasks. In order to improve employees' job performance, hotel managers could implement internal marketing practices. This can be achieved by implementing different motivation schemes for hotel employees that can increase their commitment to perform their work properly and attentively. According to previous research, employee engagement has been found as one of the drivers of employee loyalty (e.g. Lee, Kim \& Kim, 2014). Establishing loyalty towards a company is of a crucial importance in the hotel industry, as educated and skilful employees are hard to find, and even harder to retain. The perception of the quality of service in a hotel is dependent on its employees. Loyal hotel employees are already familiar with the processes adopted by the hotel, and hotel service will be consequently perceived as having a higher quality. This is especially important in the context of seasonal workforce, a significant factor in Croatia's hotel industry. Internal marketing practices can therefore increase the quality of hotel services and result in employ- 
ees devoted to their job, who perform their work in line with expectations. By using internal communication effectively and adopting one of internal marketing practices, hotel managers can influence employees to pay more attention to their work and to invest effort in performing their job as expected. This can be enhanced by investing in employee training in corporate culture and their job performance, and by clearly communicating what is expected from them. Therefore, by investing in employee training, as one of internal marketing practices, hotel marketing managers will consequently drive higher job commitment, the sense of belonging to the company and better job performance.

This study has revealed some research limitations. Firstly, the use of self-evaluations may potentially cause social desirability bias. Secondly, the study is limited to Croatian hotels. In addition, the results of different employee categories, such as supporting staff or management positions, could give more detailed insight in this field. Further research could also focus on identifying whether different employee categories would show different results related to the relationship between internal marketing and employee engagement. Furthermore, this study encompassed hotels mainly focused on summer season, so the analysis of other hotel types could reveal different results regarding internal marketing and employee engagement, due to the difference in seasonality of their workforce. Further research could also focus on finding a moderator effect, like employees' job longevity, employment status as seasonal or full time employed, the number of hotel's stars or hotel location.

\section{Acknowledgement}

This paper has been supported by the University of Rijeka under project number Uniri-drustv-18-235-1399.

\section{REFERENCES}

1. Ahmed, P., \& Rafiq, M. (2003). Internal marketing issues and challenges. European Journal of Marketing, 37(9), 1177-1186.

2. Akroush, M. N., Abu-ElSamen, A. A., Samawi, G. A., \& Odetallah, A. L. (2013). Internal marketing and service quality in restaurants. Marketing Intelligence \& Planning, 31(4), 304-336.

3. Aktar, A., \& Pangil F. (2017). The Relationship between Employee Engagement, HRM practices and Perceived Organizational Support: Evidence from Banking Employees. International Journal of Human Resource Studies, 7(3), 2162-3058.

4. Alves, H., do Paço, A., \& Roberto, C. (2015). Influence of Internal Marketing on Organizational Commitment-Evidence from Care Institutions for the Elderly. Market-Tržište, 27(2), 237-250.

5. App, S., Merk, J., \& Büttgen, M. (2012). Employer Branding: Sustainable HRM as a Competitive Advantage in the Market for High-Quality Employees. Management Revue, 23(3), 262-278.

6. Balta, S. (2018). The influence of internal marketing on employee satisfaction in the service industry. Business Management Dynamics, 8(1), 12-15.

7. Berry, L. L. (1981). The employee as customer. Journal of Retail Banking, 3, 25-28.

8. Bollen, K. A. (1989). Structural Equations with Latent Variables. New York, NY: John Wiley and Sons.

9. Boukis, A., Gounaris, S., \& Lings, I. (2017). Internal market orientation determinants of employee brand enactment. Journal of Services Marketing, 31(7), 690-703.

10. Braimah, M. (2016). Internal marketing and employee commitment in the hospitality industry. African Journal of Hospitality, Tourism and Leisure, 5(2), 1-22.

11. Brook, J. (2019). Why Employee Engagement Is Key To Company Success, Available at https:// www.socialchorus.com/blog/employee-experience/employee-engagement-key-to-company-success/ Accessed: October 20 2019. 
12. Byrne, B. M. (1994). Structural equation modeling with EQS and EQS/Windows: Basic concepts, applications, and programming. London: Sage.

13. Casey, C. (2017), 2017 Employee engagement report, Blessing White, Available at https://blessingwhite.com/2017-employee-engagement-report/ Accesed February 1" 2020.

14. Chang, C. S., \& Chang, H. H. (2007). Effects of internal marketing on nurse job satisfaction and organizational commitment: Example of medical centers in Southern Taiwan. Journal of Nursing Research, 15(4), 265-274.

15. Czaplewski, A. J., Ferguson, J. M., \& Milliman, J.F. (2001). Southwest Airlines: How internal marketing pilots success. Marketing Management, 10(3), 14-18.

16. Das, S. (2003). Vacant or engaged? Employee Benefits, March, 24-28.

17. Fornell, C. G., \& Larcker, D. F. (1981). Evaluating structural equation models with unobservable variables and measurement error. Journal of Marketing Research, 18(1), 39-50.

18. Gjurašić, M., \& Lončarić, D. (2018). Internal marketing orientation and organizational citizenship behavior in the hospitality industry - a literature review. Ekonomska misao i praksa, 1, 157-176.

19. Gounaris, S. P. (2006). Internal-market orientation and its measurement. Journal of Business Research, 59(4), 432-448.

20. Gounaris, S., Chryssochoidis, G., \& Boukis, A. (2020). Internal market orientation adoption and new service development (NSD): gearing up the internal performance of NSD teams. European Journal of Marketing, 54(7), 1641-1674.

21. Gounaris, S., Vassilikopoulou, A., \& Chatzipanagiotou, K. C. (2010). Internal-market orientation: a misconceived aspect of marketing theory. European Journal of Marketing, 44(11/12), 1667-1699.

22. Hair, J. F., Ringle, C. M., \& Sarstedt, M. (2011). PLS-SEM: Indeed a silver bullet. Journal of Marketing Theory and Practice, 19(2), 139-152.

23. Hansen, A., Byrne, Z., \& Kiersch, C. (2014). How interpersonal leadership relates to employee engagement. Journal of Managerial Psychology, 29(8), 953-972.

24. Henseler, J., Ringle, C. M., \& Sarstedt, M. (2015). A new criterion for assessing discriminant validity in variance-based structural equation modeling. Journal of the Academy of Marketing Science, 43(1), 115-135.

25. Ho, V. T., Wong, S.\&S., \& Lee, C. H. (2011). A Tale of Passion: Linking Job Passion and Cognitive Engagement to Employee Work Performance. Journal of Management Studies, 48, 26-47.

26. Homburg, C., \& Pflesser, C. (2000). A multiple-layer model of market-oriented organizational culture: Measurement issues and performance outcomes. Journal of Marketing Research, 37(4), 449462.

27. Hu, L. T., \& Bentler, P. M. (1999). Cutoff criteria for fit indexes in covariance structure analysis: Conventional criteria versus new alternatives. Structural Equation Modeling: A Multidisciplinary Journal, $6(1), 1-55$.

28. Kadic-Maglajlic, S., Boso, N., \& Micevski, M. (2018). How internal marketing drive customer satisfaction in matured and maturing European markets?. Journal of Business Research, 86(May), 291299.

29. Kahn, W. A. (1990). Psychological conditions of personal engagement and disengagement at work. Academy of Management Journal, 33(4), 692-724.

30. Kaplan, D. (2008). Structural equation modeling: Foundations and extensions (Vol. 10). Los Angeles, CA: Sage Publications.

31. Lee, Y. K., Kim, S., \& Kim, S. Y. (2014). The impact of internal branding on employee engagement and outcome variables in the hotel industry. Asia Pacific Journal of Tourism Research, 19(12), 13591380. 
32. Luthans, F., \& Peterson, S. J. (2002). Employee engagement and manager self-efficacy. Journal of Management Development, 21(5), 376-387.

33. MacCallum, R. C., Browne, M. W., \& Sugawara, H. M. (1996). Power analysis and determination of sample size for covariance structure modeling. Psychological Methods, 1(2), 130-149.

34. Ministry of tourism Republic of Croatia, 2018. Available at https://htz.hr/sites/default/ files/2018-08/HTZ\%20TUB\%20HR_\%202017\%20FINAL.pdf, Accessed: February 10 ${ }^{\text {th }}, 2020$.

35. Mitchell, C. (2000). Selling the brand inside, Harvard Business Review, 80(1), 99-105.

36. Rich, B. L., Lepine, J. A., \& Crawford, E. R. (2010). Job engagement: Antecedents and effects on job performance. Academy of Management Journal, 53(3), 617-635.

37. Roknić, S., \& First Komen, I. (2015). Primjena internog marketinga i njeni učinci na korporativnu kulturu u djelatnosti trgovine u Republici Hrvatskoj, Zbornik Veleučilišta u Rijeci, 3(1), 55-68.

38. Ruizalba, J. L., Bermundez-Gonzalez, G., Rodriguez Molina, M. A., \& Blanca, M. J. (2014). Internal market orientation: An empirical research in hotel sector. International Journal of Hospitality Management, 38, 11-19.

39. Ružić, E., \& Benazić, D. (2018). Can New Product Selling and Innovation in Sales Be Improved by Using Internal Marketing and Empowerment?. Market-Tržište, 30(1), 61-75.

40. Saks, A. M. (2006). Antecedents and consequences of employee engagement. Journal of Management Psychology, 21(7), 600-619.

41. Samra, J., Gilbert, M., Shain, M., \& Bilsker, D. (2012). About PF10: Engagement. Available at https:// www.workplacestrategiesformentalhealth.com/content/images/agenda/pdf/10_Engagement_EN.pdf, Accessed: February 10², 2020.

42. Sanchez-Hernandez, M. I., \& Miranda, F. J. (2011). Linking internal market orientation and new service performance. European Journal of Innovation Management, 14(2), 207-226.

43. Sanchez-Hernandez, I., \& Grayson, D. (2012). Internal marketing for engaging employees on the corporate responsibility journey. Intangible Capital, 8(2), 275-307.

44. Sattar, T., Ahmad, K., \& Mahnaz Hassan, S. (2015). Role of human resource practices in employee performance and job satisfaction with mediating effect of employee engagement. Pakistan Economic and Social Review, 53(1), 81-96.

45. Schaufeli, W. B., \& Bakker, A. B. (2004). Job demands, job resources, and their relationship with burnout and engagement: A multi-sample study. Journal of Organizational Behavior: The International Journal of Industrial, Occupational and Organizational Psychology and Behavior, 25(3), 293315.

46. Shuck, B., \& Wollard, K. (2010). Employee Engagement and HRD: A Seminal Review of the Foundations. Human Resource Development Review, 9(1), 89-110.

47. Sinčić, D., \& Pološki Vokić, N. (2007). Integrating internal communications, human resource management and marketing concepts into the new internal marketing philosophy. EFZG Working Paper Series, 12, 1-13.

48. Sivapragasam, P., \& Raya, R. P. (2018). HRM and Employee Engagement Link: Mediating Role of Employee Well-being. Global Business Review, 19(1), 147-161.

49. Slåtten, T., \& Mehmetoglu, M. (2011). Antecedents and effects of engaged frontline employees: A study from the hospitality industry. Managing Service Quality: An International Journal, 21(1), 88107.

50. Teimouri, H., Chegini, M. G., Jenab, K., Khoury, S., \& LaFevor, K. (2016). Study of the relationship between employee engagement and organisational effectiveness. International Journal of Business Excellence, 10(1), 37-54. 
51. Truss, C., Shantz, A., Soane, E., Alfes, K., \& Delbridge, R. (2013). Employee engagement, organisational performance and individual well-being: exploring the evidence, developing the theory. The International Journal of Human Resource Management, 24(14), 2657-2669.

52. Tsai, Y., \& Tang, T. W. (2008). How to improve service quality: Internal marketing as a determining factor. Total Quality Management, 19(11), 1117-1126.

53. Vance, R. J. (2006). Employee engagement and commitment: the guide to understanding, measuring and increasing engagement in your organisation. Alexandria, VA: The SHRM Fondation. Available at: https://www.shrm.org/hr-today/trends-and-forecasting/special-reports-and-expert-views/ Documents/Employee-Engagement-Commitment.pdf

54. Varey, R. J., \& Lewis, B. R. (1999). A broadened conception of internal marketing. European Journal of Marketing, 33(9/10), 926-944. 
APPENDIX 1: Items for internal marketing second order constructs their means, standard deviations and Cronbach's alphas

\begin{tabular}{|c|c|c|c|}
\hline Items & Mean & $\begin{array}{c}\text { Std. } \\
\text { Deviation }\end{array}$ & $\begin{array}{c}\text { Cronbach's } \\
\text { alpha }\end{array}$ \\
\hline \multicolumn{4}{|l|}{ MOTIVATION } \\
\hline $\begin{array}{l}\text { Our restaurant system of incentives s in line with objectives } \\
\text { of the hotel. }\end{array}$ & 4.71 & 1.511 & \multirow{7}{*}{0.914} \\
\hline $\begin{array}{l}\text { All staff knows the ways of rewards and how to obtain } \\
\text { them. }\end{array}$ & 4.73 & 1.673 & \\
\hline $\begin{array}{l}\text { All staff knows why they have been granted awards and } \\
\text { rewards. }\end{array}$ & 5.31 & 1.524 & \\
\hline $\begin{array}{l}\text { Our hotel system of incentives used emphasizes to motivate } \\
\text { behavior of staff for the better. }\end{array}$ & 5.22 & 1.617 & \\
\hline $\begin{array}{l}\text { Our system of incentives has a clearly defined criteria for } \\
\text { employee achievements. }\end{array}$ & 4.70 & 1.713 & \\
\hline $\begin{array}{l}\text { Our hotels management follows a system of substantial } \\
\text { incentives. }\end{array}$ & 4.67 & 1.734 & \\
\hline $\begin{array}{l}\text { Hotel management emphasizes ethical behavior of the } \\
\text { hotel staff. }\end{array}$ & 5.58 & 1.309 & \\
\hline \multicolumn{4}{|l|}{ LOYALTY } \\
\hline $\begin{array}{l}\text { There are opportunities in our hotel for advancement and } \\
\text { promotion. }\end{array}$ & 5.38 & 1.446 & \multirow{5}{*}{0.864} \\
\hline $\begin{array}{l}\text { Our hotel's administration applies the principle of staff } \\
\text { participation in decision-making. }\end{array}$ & 4.25 & 1.653 & \\
\hline $\begin{array}{l}\text { Our hotel's management gives the staff some of the powers } \\
\text { in the decision-making positions they face. }\end{array}$ & 4.20 & 1.562 & \\
\hline Our hotel distinguishes good employees. & 4.94 & 1.550 & \\
\hline Our hotel follows a system of salary commensurate with the job. & 4.58 & 1.637 & \\
\hline \multicolumn{4}{|l|}{ TRAINING } \\
\hline Our hotel has a system of personnel training. & 4.75 & 1.585 & \multirow{4}{*}{0.943} \\
\hline $\begin{array}{l}\text { Our hotel works to clarify and explain its training strategy } \\
\text { through a system of internal communications. }\end{array}$ & 4.77 & 1.594 & \\
\hline Our hotel performs training as a usual practice of business. & 4.75 & 1.621 & \\
\hline Training is available to all hotel personnel. & 4.67 & 1.754 & \\
\hline \multicolumn{4}{|l|}{ INTERNAL COMMUNICATION } \\
\hline $\begin{array}{l}\text { Internal communication is the key to the understanding of } \\
\text { staff. }\end{array}$ & 5.76 & 1.217 & \multirow{4}{*}{0.881} \\
\hline $\begin{array}{l}\text { Our internal communication is in line with the external } \\
\text { communications with customers. }\end{array}$ & 5.40 & 1.193 & \\
\hline $\begin{array}{l}\text { In our hotel there is a strong relationship between the } \\
\text { management and staff. }\end{array}$ & 5.26 & 1.395 & \\
\hline $\begin{array}{l}\text { Our internal communication is the key which provides } \\
\text { information from management to all staff. }\end{array}$ & 5.40 & 1.240 & \\
\hline
\end{tabular}

